\title{
Forest Insects and Climate Change
}

\author{
Deepa S. Pureswaran ${ }^{1} \cdot$ Alain Roques $^{2} \cdot$ Andrea Battisti $^{3}$
}

Published online: 30 April 2018

(C) The Author(s) 2018

\begin{abstract}
Purpose of Review Climate change affects populations of forest insect pests in a number of ways. We reviewed the most recent literature (2013-2017) on this subject including previous reviews on the topic. We provide a comprehensive discussion of the subject, with special attention to insect range expansion, insect abundance, impacts on forest ecosystems, and effects on forest insect communities. We considered forest insects according to their major guilds and biomes.

Recent Findings Effects of climate change on forest insects are demonstrated for a number of species and guilds, although generalizations of results available so far are difficult because of species-specific responses to climate change. In addition, disentangling direct and indirect effects of climate change is complex due to the large number of variables affected. Modeling based on climate projections is useful when combined with mechanistic explanations.

Summary Expansion of either the true range or the outbreak range is observed in several model species/groups of major insect guilds in boreal and temperate biomes. Mechanistic explanations are provided for a few species and are mainly based on increase in winter temperatures. In relation to insect abundance, climate change can either promote outbreaks or disrupt trophic interactions and decrease the severity of outbreaks. There is good evidence that some recent outbreaks of bark beetles and defoliating insects are influenced by climate change and are having a large impact on ecosystems as well as on communities of forest insects.
\end{abstract}

Keywords Biome $\cdot$ Community $\cdot$ Guild $\cdot$ Impact $\cdot$ Outbreak $\cdot$ Range $\cdot$ Review

\section{Introduction}

There is general consensus among scientists that the global climate is changing at an unprecedented rate, with many regions experiencing warming trends, frequent high temperature extremes, and shifts in precipitation patterns $[1 \bullet \bullet$. An increase of $0.61^{\circ} \mathrm{C}$ in global mean temperature recorded since the beginning of the twentieth century (i.e., comparing the years $1850-1900$ and $1986-2005,5-95 \%$ CI is

This article is part of the Topical Collection on Forest Entomology

Deepa S. Pureswaran

deepa.pureswaran@canada.ca

1 Natural Resources Canada, Canadian Forest Service, Laurentian Forestry Centre, 1055, rue du PEPS, Québec, QC G1V 4C7, Canada

2 Institut National de la Recherche Agronomique (INRA), UR 0633, Zoologie Forestière, 45075 Orléans, France

3 Department of Agronomy, Food, Natural resources Animals and Environment (DAFNAE), University of Padova, 35020 Legnaro, Italy $\left.0.55-0.67^{\circ} \mathrm{C}\right)[1,2]$, and the predicted warming of $2-6{ }^{\circ} \mathrm{C}$ by 2100 [3] have direly increased the need to understand the impacts of climate change.

Interactions and feedbacks between climate and the health of forest ecosystems are expected [4]. Changes in disturbance patterns mediated by climate warming are predicted to be the greatest impacts on forests in the coming decades [5]. Current increases in frequency and intensity of biotic and abiotic disturbances to forest ecosystems have been attributed, at least in part, to climate change $[1 \bullet \bullet$, but uncertainties remain in a number of cases. Outbreaks of forest insects are major agents of mortality and ecosystem change in forests worldwide, and climate has been attributed to be an important driver of changes to disturbance regimes mediated by forest insects. Largescale tree mortality resulting from drought, fire, and/or insect outbreaks can result in loss of carbon sinks and have feedbacks on climate change, with serious consequences for biodiversity and ecosystem function $[6 \cdot 7]$.

Disturbances have been defined as "disrupting the function of an ecosystem and changing resource availability or the physical environment" [5]. Consequences of disturbance can result in loss of resilience accompanied by major ecological 
transformations [8]. Forest insect outbreaks are major disturbances by native or non-native insects, as they can be synchronous over large geographic areas and cause region-wide mortality of host trees in a relatively short period of time [9, $10,11 \cdot 12]$. Disturbance due to forest insects have been recorded to increase land surface temperature and cause declines in gross primary productivity $[13,14]$.

Predicted geophysical impacts of climate change include floods, droughts, and rise in sea levels. General circulation models predict the greatest warming at high latitudes in winter, a decrease in precipitation at mid-latitudes in summer, and an increase in frequency of extreme climatic events such as storms and droughts [4]. Bark beetles, for example, can cause tree mortality following severe drought that is associated with warm temperatures, due to positive feedbacks on their populations from availability of susceptible hosts and favorable temperatures, amplified over spatial and temporal scales $[10$, 15•]. Predictions of insect outbreaks suggest changes in spatiotemporal patterns of defoliators and bark beetles. Bentz et al. [16] predict that spruce bark beetle, Dendroctonus rufipennis, outbreaks may occur throughout the range of spruce in North America in the future. Outbreak dynamics of the spruce budworm, Choristoneura fumiferana, are predicted to change, move further north, and on to secondary host species [17, 18]. Similarly, cyclical outbreaks of larch bud moth, Zeiraphera griseana, are predicted to decrease in magnitude in optimal mid-elevation zones of the Alps, and to shift toward higher altitudes [19]. However, predictions on future outbreak dynamics of defoliators remain uncertain as there is conflicting evidence on outbreak severity [20]. In general, poleward and upward shifts of pests and pathogens have been documented, but predictions are complicated due to interactions and uncertainties associated with changing weather patterns, extreme climate events, and differing responses of plants and insects to these events [21]. The consequences of higher frequency of extreme events are still poorly documented. For example, both positive and negative effects of climate on expansion and population dynamics can occur, as was observed in the pine processionary moth, Thaumetopoea pityocampa, during summer heat waves in 2003. This heat wave led to a collapse of the front edge population in France by killing early stages of the insect [22], while at the same time, triggering a record annual expansion in the Italian Alps by facilitating female flight [23].

Insect populations are particularly responsive to climate change because of their sensitivity to temperature, short generation times, and high flight capacity. Observations of insect herbivory on an oak lineage during Quaternary climate change indicate that there was higher damage during warm and wet periods [24]. In recent years, the magnitude and severity of epidemics have increased, with outbreak populations expanding to northern and high-elevation areas, where in the past, such disturbances were relatively rare $[10,18,25 \bullet]$.
Long-term surveys and examination of outbreak dynamics of five species of European Lepidoptera between 1800 and 2011 revealed climate-driven changes in outbreak severity, cyclicity, and frequency, but there were mixed effects of temperature on outbreak activity [12, 26, 27]. It is often argued that the frequency and severity of $C$. fumiferana outbreaks in North America have increased in the twentieth century. A regional tree ring chronology study [28] represents the longest and most replicated reconstruction of outbreak dynamics in North America (1551-1995). They identified nine potential outbreaks and three uncertain outbreaks in a 400-year period and concluded that while outbreak frequency was higher during the twentieth century ( $\sim 30$ years) compared to the 1660 1850 period ( $\sim 50$ years), higher outbreak frequency might have occurred prior to 1660 ( $\sim 28$ years). While there is evidence that recent warmer temperatures have permitted the expansion of bark beetle outbreaks to higher latitudes and elevations than in the past, similar trends are more ambiguous to discern for Lepidoptera [20].

Reports of forest decline are becoming more frequent and habitat shifts are occurring throughout the continental USA, bringing to the limelight the importance of interactions involving drought, insects, and fire [29]. Climate and weather can have direct effects on trees, as drought and storms can weaken trees and predispose them to attack by bark beetles and pathogens. Climate can also have direct effects on insects as they are small poikilotherms with limited thermoregulation ability [30]. For example, in the hemlock wooly adelgid, Adelges tsugae, nymphs were observed 3 months ahead of their normal phenology in December 2015, the warmest recorded December in Tennessee, USA, accelerating their development [31]. Intense but not moderate drought appears to favor bark beetle performance and tree mortality, although its impact is not consistent among species [32]. Warm temperatures result in changes in physiology and accelerated development in insects [33], particularly in northern latitudes where the growing season is short. Changes in phenology and phenological mismatches with host trees and/or natural enemies can alter trophic relationships and either favor or be detrimental to forest insect populations [34, 35]. Physiological changes in insects in response to temperature can facilitate changes in their distribution patterns [21]. Field-based experimental manipulations of host plants [36] and insects to determine their relative responses to changes in temperature [37-39] can help predict the nature and extent of range shifts and to better understand how forest ecosystems will respond to climate change [40].

In this paper, we review the current state of knowledge on the response of forest insects to climate change, with special attention to insect range expansion, population dynamics, and impacts on communities and forest ecosystems. We systematically analyzed literature from the past 5 years (2013-2017) for direct, indirect, and interacting effects of climate change on forest insect outbreaks and used reviews from earlier 
publications (e.g., [41•]). We compiled information from different biomes and geographical areas on the effect of climate change on forest insects, dealing with range expansion, population abundance, host shifts, and community interactions. We highlight the importance of using experimental manipulations to test the effect of climate warming on the phenology and performance of host trees, forest insects, and their natural enemies to better predict the response of communities and ecosystems to climate change. We identify gaps in current knowledge and suggest areas for future research that would advance our understanding of the impacts of climate change.

\section{Literature Review and Analysis}

We screened the peer-reviewed literature between 1948 and 2017 using Scopus on 7 July 2017 with "forests" AND "insect*" AND "climat*" AND "chang*" as our search terms. We obtained 1246 hits of papers containing these terms in the title, key words, or abstract. We focused our search on papers published between 2013 and 2017, and removed papers where the title or abstract revealed that they were not relevant. A total of 213 papers were selected for further analysis. These papers were classified based on whether they addressed (1) climatic drivers (temperature, precipitation, wind, $\mathrm{CO}_{2}, \mathrm{O}_{3}$ ); (2) their biomes (subarctic, boreal, temperate, subtropical or tropical); (3) forest type (natural or planted); (4) forest interactions (fire, drought, growth, dispersal, carbon, pathogens, trade); (5) feeding guilds (defoliators, bark beetles and wood borers, gall makers, sap suckers, seed and cone insects); (6) response of plants and/or insects (performance, phenology, voltinism); and (7) outcomes of climate change (range shift, host shift, outbreak dynamics). Forty of these papers were reviews or book chapters, which we then separated from the primary literature. We further added relevant papers that were accepted or in press and not picked up by Scopus.

\section{Range Expansion}

The range edge of forest herbivores is not easy to detect, especially when populations occur at low densities [41•]. Consequently, range expansion is difficult to document in nature, unless individuals are conspicuous, occur at high density, or cause obvious symptoms on trees. There are a few species of native forest insects for which range expansion has been precisely ascertained and related to climatic variables, including T. pityocampa [42] and bark beetles [10]. In addition, introductions of non-native forest insects into novel geographic areas represent an opportunity to assess potential range expansion zones, although in this case, it is not always clear whether the expansion is limited by niche availability or climatic factors [43]. Through analysis of case studies reported in Table 1, we address the above questions and provide an interpretation that could facilitate further research in this field.

\section{Defoliators}

Range expansion linked to climate change has been observed in a dozen model species/groups in the boreal and temperate biomes, with mechanistic explanations provided for a few species. Increase in winter temperature appears to be the factor facilitating the survival and the occupation of geographic areas that were previously inaccessible due to harsh climate. Such a direct effect has been observed for geometrids associated with mountain birch, the autumnal moth, Epirrita autumnata, and the winter moth, Operophtera brumata, in the boreal areas of northern Europe, where eggs now encounter more favorable conditions during winter [46, 47]. In the case of T. pityocampa in Europe, larvae intensify feeding with more permissive winter temperatures, resulting in range expansion that is independent of population outbreaks $[23,42$, 49] (Fig. 1). An interesting indirect effect involving the host plant has been hypothesized and modeled for C. fumiferana in Canada, which is associated with balsam fir as its main host and black spruce as a secondary host. Climate change is predicted to advance the phenology of the secondary host that is more abundant at the upper latitudinal edge, making it more susceptible to defoliation during outbreaks, and thus facilitating expansion of the outbreak area into higher latitudes [17, 18, 44, 45, 70] (Fig. 1). In Z. griseana, increased late winter and early spring temperatures create a phenological mismatch between larval hatching and spring budburst of larch at the optimal elevation belt (1800-2000 m), resulting in a shift toward higher elevations $[51,52]$. Models are available to predict further range expansion of species for which the mechanism of response is known, and tests with independent data have shown they are reliable [71, 72]. However, generalization is difficult because of the specificity of reaction norms and ecological adaptations.

Other species have been observed to expand their ranges, and often, climate change has been invoked to explain these patterns. Climate-matching models, that may or may not include species-specific parameters, have been used to predict future scenarios. These tools are useful to build hypotheses about mechanisms and to encourage scientists to design experiments tailored to individual species, although we should use caution before drawing general conclusions about the effects of climate change on range expansions [73-75].

Non-native defoliators also expand their range in response to climate change. In the case of the gypsy moth, Lymantria dispar, in North America, the reaction norm of larvae varies within the range, with local adaptations that may explain recent colonization of the upper part of the range [48]. This 
Table 1 Range expansion of forest insect pests

\begin{tabular}{|c|c|c|c|c|c|c|}
\hline Guild & Biome & Area & Species & Host & Approach or factors considered & References \\
\hline \multirow[t]{5}{*}{ Defoliators } & \multirow[t]{2}{*}{ Boreal } & Canada & Choristoneura fumiferana & Abies, Picea & Phenology match, models & {$[17,18,28,44,45]$} \\
\hline & & Scandinavia & Geometrids & Betula & Winter survival & {$[46,47]$} \\
\hline & \multirow[t]{3}{*}{ Temperate } & N. America* & Lymantria dispar & Broadleaves & NA & [48] \\
\hline & & Europe & Thaumetopoea pityocampa & Pinus, Cedrus & Winter survival & {$[22,42,49,50]$} \\
\hline & & Europe & Zeiraphera griseana & Larix, Picea & NA & {$[51,52]$} \\
\hline \multirow{3}{*}{$\begin{array}{l}\text { Bark beetles and } \\
\text { wood borers }\end{array}$} & \multirow[t]{3}{*}{ Temperate } & N. America* & Agrilus planipennis & Fraxinus & NA & [53] \\
\hline & & N. America & Dendroctonus frontalis & Pinus & Winter survival & {$[54,55]$} \\
\hline & & N. America & Dendroctonus ponderosae & Pinus & Winter survival, model & {$[56-63]$} \\
\hline \multirow{2}{*}{$\begin{array}{l}\text { Other guilds: } \\
\text { Seedling feeders }\end{array}$} & \multirow[t]{2}{*}{ Temperate } & N. America & Dendroctonus rhizophagus & Pinus & Model & [64] \\
\hline & & Europe & Hylobius abietis & Pinus & Model & {$[65]$} \\
\hline \multirow[t]{2}{*}{ Gall makers } & \multirow[t]{2}{*}{ Temperate } & Europe* & Andricus spp. & Quercus & NA & {$[66]$} \\
\hline & & Europe* & Dryocosmus kuriphilus & Castanea & NA & {$[67]$} \\
\hline Sap suckers & Temperate & N. America* & Adelges tsugae & Tsuga & Winter survival & {$[31,68,69]$} \\
\hline
\end{tabular}

*Non-native species

indicates that selection can act on a relatively short time scale to enable populations to quickly adapt to new conditions caused by climate change.

\section{Bark Beetles and Wood Borers}

Bark beetles of the genus Dendroctonus have recently provided evidence of range expansion in North America where they are responsible for large outbreaks in different geographical regions. In the southeastern USA, the southern pine beetle, Dendroctonus frontalis, is moving north due to milder winters that enhance performance $[54,55]$. In the north-west, the mountain pine beetle, Dendroctonus ponderosae, is expanding northward and eastward for the same reason $[56,57,71]$. These obligate tree-killing insects require a large number of individuals to mass-attack trees and overcome their defenses. As they can disperse for long distances, it is difficult to precisely define the edge of their range and document expansions. Most of what is known depends on the availability of precise information on the location of dead trees and the cause of death, which are now available due to modern surveillance technology. These species are difficult to detect when associated with weakened trees under endemic conditions, whereas damage and tree mortality become obvious during epidemics. Therefore, the range edge generally considered is that of the epidemic range, and the margins of the endemic range remain largely unknown. During the expansion of the epidemic range of North American Dendroctonus spp., a number of interactions directly or indirectly related to climate change have played an important role $[58,59 \bullet, 60-62]$. Increase in temperature resulted in higher beetle performance, change in phenology, associated microbes, and their interactions. The northward and eastward expansion of $D$. ponderosae in Canada exposed a new host species, jack pine, to attack and successful colonization by the beetle, resulting in the invasion of previously unoccupied regions $[60,63 \cdot]$ (Fig. 1). Bentz and Jönsson [62] review quantitative models that predict the influence of temperature and precipitation on bark beetle outbreaks. Ecological niche models such as Maxent are now used for several species to match suitable climate habitats and predict range expansions [63•].

Although we have evidence of range expansion for other bark and wood-boring insects, the mechanisms have not yet been clearly explained. Of these, two non-native insects that became invasive in various parts of the world, the emerald ash borer, Agrilus planipennis [53], and the Sirex woodwasp, Sirex noctilio [76], have large expansion potential in their newly invaded areas. Human-mediated transportation has been attributed to have facilitated the expansion of A. planipennis in the USA.

\section{Other Guilds}

Two native species feeding on seedlings, one scolytine beetle [64] and one weevil [65], have been considered in climatematching studies, and in both cases, there is potential for range expansion with increasing temperature under different scenarios of climate and host plants. Similarly, climate-matching provides estimates of range expansion for a few species of non-native gall makers, such as cynipid gall wasps $[66,67]$ and sap suckers. The best studied species is A. tsugae in eastern North America, which is expanding its range due to low winter mortality, fast development rates in early spring [31, $68,69]$, and improved potential to overcome cold snaps [77]. 

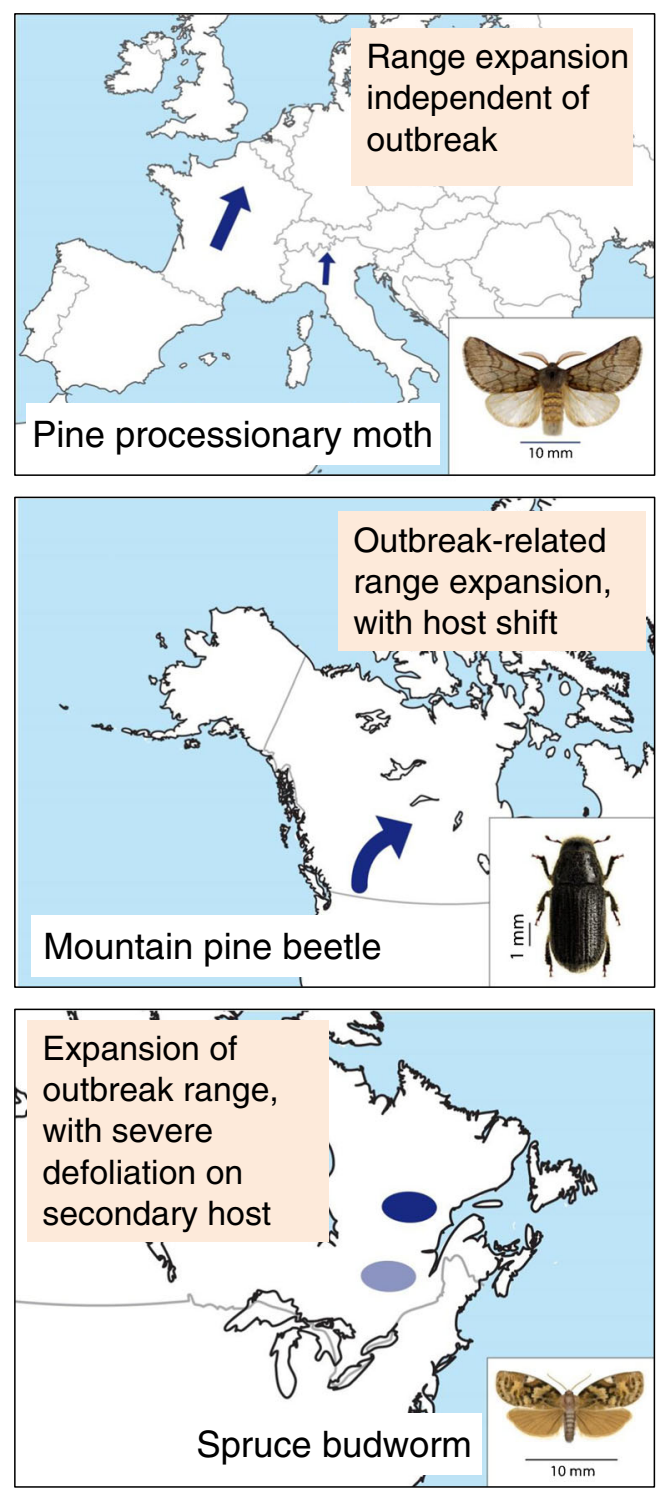

Fig. 1 Scenarios of range expansion related to climate change in three important forest pests, the pine processionary moth, T. pityocampa (large arrow: latitudinal expansion in northern France, small arrow: elevational expansion in the Italian Alps), the mountain pine beetle, D. ponderosae (the arrow indicates the expansion from British Columbia to Alberta), and the eastern spruce budworm, C. fumiferana (light blue oval: outbreak of 1962-1992, dark blue oval: current outbreak, 2006-present)

\section{Range Expansion Rates}

Estimates of the speed at which forest insects are expanding are available for a few species and rely mainly on comparing the edge of the expansion front over time, varying from a few hundred meters in T. pityocampa in the Alps, to hundreds of kilometers in C. fumiferana in Canada. Although this is largely dependent on the local population density of insects, dispersal potential alone does not determine expansion. Climatic and host-related factors in the new range are crucial for the successful establishment of expanding populations. There are, however, cases when dispersal occurs under particularly suitable climatic conditions, such as warm nights that favor the spread of moths at the range edge [23]. In D. ponderosae, rates of spread and thereby, range expansion, can be determined using dispersal rates and population growth rates that are governed by host tree interactions as well as climate [71]. Inadvertent human transportation of insects can facilitate range expansion in both native [50] and non-native pests $[53,78]$. In non-native pests, it can be difficult to disentangle active from passive dispersal, unless genetic fingerprinting of expanding populations reveals how they arrived in the new range.

\section{Insect Abundance}

The effects of climate change on insect performance are important to predict population trajectories of forest insects and the impacts of outbreaks on forest ecosystems [63•] (Table 2). Temperature and precipitation have direct impacts on trees and are major drivers of population change in insects. Most of the data available so far on forest insect epidemics are restricted to temperate and boreal ecosystems. In temperate climates, insects respond positively to temperature [33] and their abundance can peak at warm temperatures [89]. Warm spring temperatures can also favor tree growth, advance budburst, and produce high-quality foliage that can potentially aid early larval feeding. Hot, dry summers can modify tree defenses and resistance to herbivory. Elevated temperature and ozone can increase the emission of volatile organic compounds and modify herbivory [84]. Temperate insects are generally cold tolerant and exhibit adaptations such as diapause and super-cooling tolerance that can facilitate shifts to northern latitudes or higher elevations even with a slight increase in temperature [85]. However, warm temperatures can be deleterious by disrupting development rates and diapause requirements [44]. Climate change can therefore either favor outbreaks, or disrupt trophic interactions, and decrease the severity of outbreaks (Table 2). For example, variation in precipitation negatively affects caterpillar parasitism [106]. Also, outbreaks of Z. griseana across the Alps have collapsed since the 1980s [93], even though recent temperatures are warmer than those of the past.

\section{Defoliators}

In boreal and temperate defoliators, an increase in temperature generally favors population growth. Increasing temperature and precipitation had positive effects on tree growth during an epidemic of $C$. fumiferana [79], potentially increasing early instar larval survival. Tree ring chronologies of jack pine budworm, Choristoneura pinus, revealed that cool May temperatures followed by warm, dry summers favored outbreaks on 


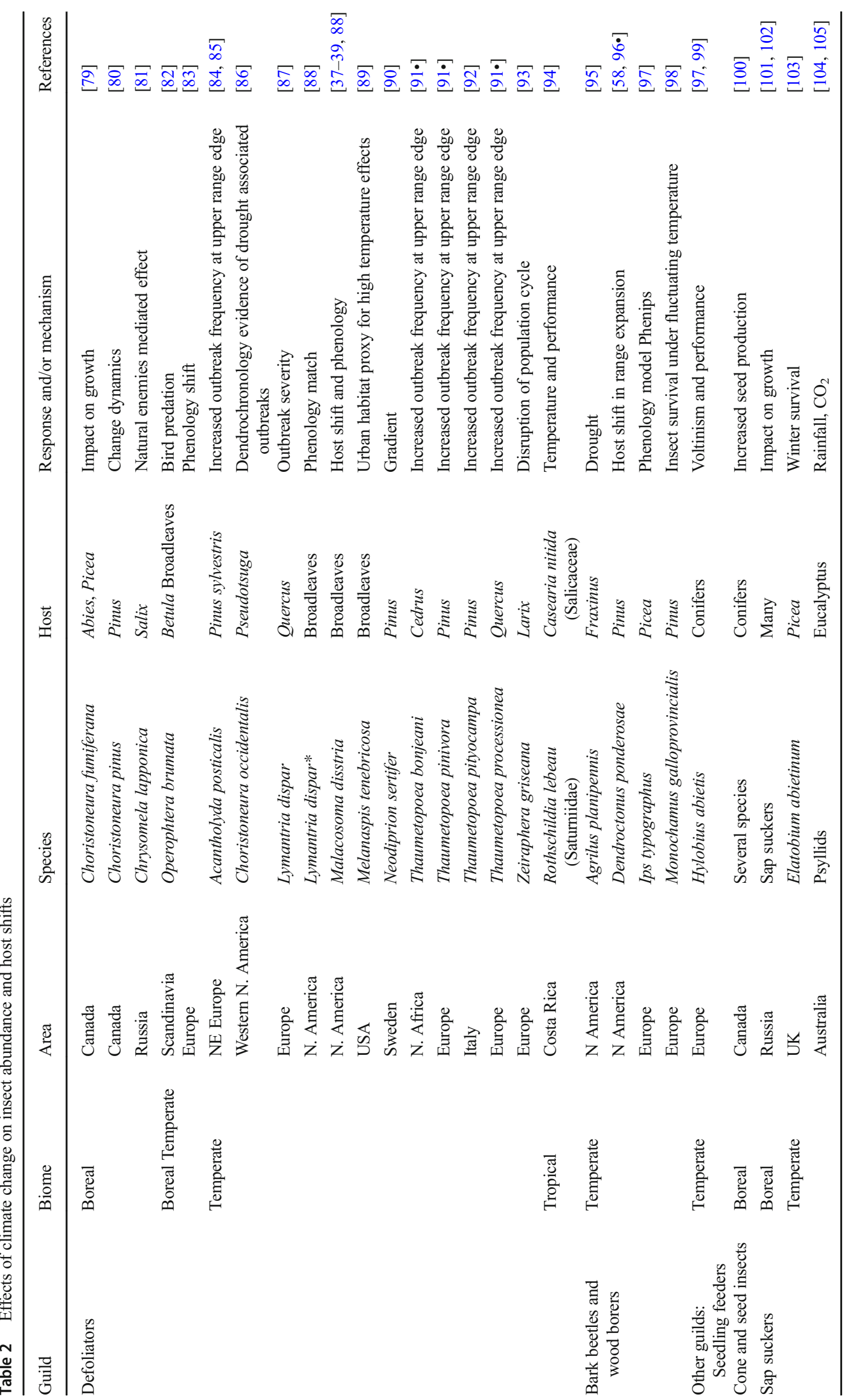


jack pine and scots pine between 1956 and 1986, resulting in five outbreaks of $C$. pinus, with jack pine being primarily affected, and scots pine showing a 1-year lag in defoliation [80]. Similar dendrochronological evidence suggests that western spruce budworm, Choristoneura occidentalis, outbreaks increased after 1890 in northwestern USA when fire disturbance decreased and that outbreaks generally began near the end of warm, dry periods [86]. In Europe, populations of T. pityocampa respond positively to higher than average summer temperature and spring rainfall, although the mechanisms are unclear and patterns vary depending on local environmental conditions [92]. Increased outbreak frequency at upper range limits have been observed in several Thaumetopoea spp., but the link with climate warming is still to be ascertained [91•]. Higher temperatures did not affect survival, but reduced development time of sawflies by up to $41 \%$ [90], potentially increasing the risk of outbreaks. If larval development time is shorter at warmer temperatures, predation risk could decrease. However, interactions can be complex, as performance of natural enemies can also improve with warmer temperatures [107].

Positive relationships between temperature, drought, and herbivory do not necessarily occur. Dendrochronological analyses of $Z$. griseana outbreaks over 500 years reveal periodicities of 4,8 , and 16 years throughout the time series, except during 1690-1790, and since 1980, suggesting that disruption of periodicity may be related to changes in climate [93]. Although still peaking at 8-10-year intervals, present outbreaks show a ca. threefold decrease in larval density compared to the outbreaks that occurred before the 1970s (Roques, unpublished data). Manipulative forest warming mesocosm experiments enable us to quantify the relative responses of host trees and their herbivores to changes in ambient temperature. Studies using forest tent caterpillar, Malacosoma disstria, and its host trees under controlled conditions examined its relative response to changes in temperature [37-39]. Under warmer temperature regimes in late winter and spring, tree phenology generally advanced more than insect phenology, altering synchrony between $O$. brumata and oak budbreak in the Netherlands between 1975 and 2000 [83, 108]. However, in some years, eggs may hatch up to 30 days before oak leaves appear, although this effect is not predicted to be consistent. Genetic variability in the date of egg hatch, and possible host shifts, are likely to allow adaptation through severe selection in the original population [109].

In dry, tropical forests, high temperature and low precipitation decreased growth and development of Saturniid caterpillars feeding on Salicaceae, compared to cooler, wetter conditions [94]. Young oak trees did not suffer greater herbivory when exposed to $L$. dispar larvae under drought conditions [87], and inadequate winter chilling disrupted synchrony between $L$. dispar and its host trees, potentially decreasing the severity of outbreaks [88]. In four species of leaf beetles,
Chrysomela spp., that feed on willows in subarctic Russia, spring and fall temperatures increased by 2.5 to $3.0^{\circ} \mathrm{C}$ over a 21-year period (1993-2014) [81]. While host plant quality increased with temperature, beetle abundance did not increase. Chrysomela lapponica populations actually declined due to the impact of natural enemies and declining pollution, suggesting that changes in air quality might confound data on long-term population dynamics. Trophic interactions can affect population abundance and outbreak dynamics. In subarctic mountain birch forests, defoliation rates are higher during outbreaks in high elevations. Pepi et al. [82] showed that predation rates on E. autumnata and O. brumata larvae were almost twice as high in low versus high elevation sites, and that release from predation pressure at high elevations can favor outbreaks in these cooler habitats. It therefore appears that top-down effects can override bottom-up effects of climate warming in some tri-trophic systems.

\section{Bark Beetles and Wood Borers}

Population abundance and outbreaks of bark beetles are generally related to drought, except for $D$. frontalis, for which the relationship with precipitation is obscure [32]. D. ponderosae outbreaks occur throughout western North America and the recent outbreak in British Columbia, Canada, was unprecedented in its scale and impact [10]. By the end of the outbreak, populations of the beetle had breached the Rocky Mountains, and moved into the boreal forest where host shifts and reproduction on jack pine, a novel host species, have been recorded. Other species of potential hosts include red pine and eastern white pine. Novel hosts exhibited lower defenses to attack than co-evolved hosts such as lodgepole and ponderosa pine [96•]. Warmer temperatures associated with climate change are a significant factor in recent outbreaks and range expansion of $D$. ponderosae due to positive influences on development phenology and winter survival $[110,111]$. Diapause and winter survival influence voltinism and population abundance. Whether or not $D$. ponderosae population structure and voltinism would change with warmer temperatures has been speculated. Along latitudinal and elevational gradients in the western USA, the number of days required to complete a generation was similar in both cool and warm sites. [61, 62]. Thermal units required to complete a generation were lowest at cool sites, but individuals did not become bivoltine even at the warmest sites. The need to maintain cold sensitive life stages in the winter prevents bivoltinism from evolving in this species $[61,62]$. There is evidence that the invasion of populations into more northern latitudes was possible due to changes in cellular and metabolic functions, with genome scale differentiation, that allow populations to better withstand cooler northern climates and facilitate longer dispersal distances. Such landscape-wide selective adaptation has permitted 
D. ponderosae populations to colonize and reproduce in previously inaccessible areas [59॰].

The likelihood of bivoltinism in D. rufipennis as the climate warms is also uncertain because it inhabits relatively colder habitats that necessitate obligate winter diapause and slow developmental rates [112]. In its coldest locations, D. rufipennis is semivoltine, having a generation every 2 years. In these areas, cool temperatures experienced by larvae can result in a facultative pre-pupal diapause, followed by an obligate diapause by teneral adults the following winter. In a warmer climate, accelerated development could result in populations transitioning to univoltine life cycles due to elimination of the pre-pupal diapause phase [112]. The phenology of the European spruce bark beetle, Ips typographus, has been predicted with models such as PHENIPS [112] to estimate flight periods, diapause, and development in the context of climate change. Berec et al. [97] predict that changes in voltinism will not exceed two generations per year, as they expect only minor changes in development time under current climate change scenarios. At the southern edge of the range, however, under warm autumn conditions, a third generation can be produced, with emerging beetles dispersing in the spring and summer [113]. Multivoltine populations of I. typographus have resulted in high timber loss at low and medium elevations of the southeastern Alps [113].

In the longhorn beetle, Monochamus galloprovincialis, a vector of the invasive pinewood nematode, temperature fluctuations decrease longevity, while there is no effect of ambient higher temperatures on survival [98]. Another highly invasive species, A. planipennis, is predicted to drive ash, Fraxinus spp. to extinction in North America, as current and future winter temperatures may not be cold enough to cause significant mortality of larvae in much of its invaded range [95].

\section{Other Guilds}

Voltinism of the pine weevil, Hylobius abietis, is expected to increase with climate change as well as the impact on regeneration, with severe implications on management practices [100, 114]. Seed and cone insects are poorly studied in relation to climate change response. Since most species are host-specific and depend on tight synchrony with cone development to share the cone niche [115-117], climate change is likely to affect interactions between cones and insects as well as between insect species. However, adult emergence of three species of larch cone flies, Strobilomyia spp., appeared to adjust tightly to the earlier blossoming of larch in the Alps, which has advanced 12-15 days since the 1980s (Roques, unpublished observations). Reproductive loss occurred in about $85 \%$ of black spruce, Picea mariana; balsam fir, Abies balsamea; eastern larch, Larix laricina; and white spruce, Picea glauca; sampled across three treeline zones in the Mealy Mountains in Labrador, suggesting that cone insects can limit treeline expansion due to climate change [118]. Drought prompts outbreaks of the green spruce aphid, Elatobium abietinum, only at moderate levels of tree stress, and climate change seems to facilitate outbreaks [103]. In Australia, outbreaks of eucalypt psyllids are dependent on rainfall affecting changes in host quality, although the roles of climate change and $\mathrm{CO}_{2}$ enrichment remain to be clarified $[104,105]$.

\section{Outbreaks Related to Climate Change Effects on Forest Ecosystems}

Impacts of insect outbreaks due to climate change effects on forest ecosystems have become evident in recent years and are summarized in Table 3. Outbreaks impact forest ecosystems and the mechanisms are dependent on the insect guild and region [132]. Impacts can vary from fluctuations in tree growth to changes in the succession of the ecosystem, whereby forest regeneration may not occur to replace dead trees. Although the relationships between climate change and outbreak propensity of forest insects are still a matter of discussion (see previous chapter), some recent outbreaks (e.g., $D$. ponderosae), have large impacts on the ecosystem and can generate feedbacks on climate change $[6,133]$. The mechanisms by which insect outbreaks may affect ecosystem dynamics are numerous, and in the analysis below, we address them in defoliators and bark and wood-boring insects.

\section{Defoliators}

The impact of defoliation in boreal ecosystems are the bestknown models. The $C$. fumiferana outbreak in Canada is linked to an increase in both tree mortality and fire ignition. However, observations during the past few decades and predictions based on climate scenarios document an overall reduction of impacts or a shift to higher latitudes $[119,120]$. In northern Europe, the impacts of natural and simulated defoliation by geometrids on the growth of mountain birch, under controlled conditions mimicking climate change, do not appear to be important, and may depend on interactions with water and nutrient availability [121,122]. The effects of geometrid defoliation in the outbreak range expansion area are instead rather conspicuous, as they involve a shift from oligotrophic to eutrophic communities in the understory layer [123], with consequences for the abundance of mammalian herbivores [25•]. An interesting study on the abundance of an insect herbivore of an understory plant along a temperature gradient has shown that insect abundance is temperature-limited while the plant is not, indicating a potential for increased herbivory with climate change [125]. In North America, defoliation of M. disstria appears to reduce the capacity of aspen to cope with climate change-related droughts, although the mechanisms are not clearly elucidated [126]. Similarly, defoliation of the 
Table 3 Outbreaks related to climate change effects on forest ecosystems and host tree distribution

\begin{tabular}{|c|c|c|c|c|c|c|}
\hline Guild & Biome & Area & Species & Host & Response and/or mechanism & References \\
\hline \multirow[t]{6}{*}{ Defoliators } & \multirow[t]{3}{*}{ Boreal } & Canada & Choristoneura fumiferana & Abies, Picea & $\begin{array}{l}\text { Defoliation of spruce } \\
\text { budworm and fire ignition } \\
\text { and tree mortality }\end{array}$ & {$[119,120]$} \\
\hline & & Finland & Geometrids & Betula & Impact of defoliation on growth & {$[121,122]$} \\
\hline & & Scandinavia & Operophtera brumata & Broadleaves & Understory vegetation change & {$[18,123]$} \\
\hline & Sub-boreal & Altaj Russia & Dendrolimus sibiricus & Abies & Increase of defoliation & [124] \\
\hline & \multirow[t]{2}{*}{ Temperate } & Europe & Cheilosia fasciata & Allium ursinum & $\begin{array}{l}\text { Host plant abundance along } \\
\text { elevation gradient }\end{array}$ & {$[125]$} \\
\hline & & N. America & Malacosoma disstria & Populus & Starting decline by defoliation & {$[126]$} \\
\hline $\begin{array}{l}\text { Bark beetles and } \\
\text { wood borers }\end{array}$ & Temperate & N. America & Dendroctonus ponderosae & Pinus & $\begin{array}{l}\text { Host plant range shrinking. } \\
\text { Relationships with wild fire. } \\
\text { Impacts on carbon }\end{array}$ & [127-131] \\
\hline
\end{tabular}

Siberian moth, Dendrolimus sibiricus, on fir has been associated with climate change in central Asia, and with significant tree mortality [124].

\section{Bark Beetles and Wood Borers}

The recent outbreak of $D$. ponderosae in North America was a magnitude larger in area and severity than previously recorded outbreaks, resulting in questions on long-term impacts of tree mortality on forest ecosystems. The range of one of its dominant pine hosts, lodgepole pine, appears to shrink at the lower edge, as seedling recruitment does not compensate for the accelerated mortality of trees [127]. Wildfires and bark beetle outbreaks are often correlated, as they respond to common climatic drivers, rather than to their interactions [128, 129]. The outbreak converted forests that were net carbon sinks into net carbon sources for several years during following the outbreak, due to severe reduction in net primary production [6, 133]. However, simulations of long-term impacts on the carbon cycle and regeneration of killed stands of lodgepole pine predict potential recovery from tree mortality, depending on local climatic conditions and natural vegetation $[130,131]$. In the Greater Yellowstone ecosystem, high-elevation whitebark pine that was previously not affected by the beetle due inhospitable climate is now being killed by $D$. ponderosae [134]. It appears that whitebark pine mortality will continue, and regeneration will be slow [134], making research and forest management high priorities in this vulnerable ecosystem.

\section{Impact of Climate Change on Forest Insect Communities}

Climate change is predicted to disrupt trophic interactions if one or more members of the community respond positively or negatively to changes in temperature or precipitation. In particular, species may shift their phenology at different rates, having cascading and potentially deleterious effects on the community (Table 4). A 40-year time series of phenological events in plants, birds, reptiles, insects, and fungi in Russia revealed that phenology advanced most significantly in plants, compared to other taxa. However, inter-annual variation in plants, reptiles, and insects was highly synchronized, indicating that there was a community-level shift in phenological synchrony [136], suggesting that communities may have a certain adaptive capacity to resist changes in phenological synchrony. In general, with increasing climatic variability, parasitism levels are predicted to decrease as host-specific parasitoids would have difficulties tracking host populations [106]. Parasitism rates and parasitoid diversity also decreased with elevation, with endoparasitoids of endophagous insects being most protected from the impacts of climate change [144]. Outbreaks of phytophagous insects are therefore predicted to increase because of lower parasitism rates as the climate warms [106, 144].

\section{Defoliators}

Herbivory is associated with budburst and tree growth, both of which respond strongly to temperature. Herbivore density, diversity and consumption of foliage on high latitude genotypes of silver birch, Betula pendula, were correlated with birch phenology, providing evidence that climate indirectly affects herbivore communities [137]. While it is generally proposed that climate-induced herbivory will increase at higher latitudes, this has seldom been tested. Diversity and abundance of leaf miners of birch from $59^{\circ}$ to $69^{\circ} \mathrm{N}$ in Europe decreased with latitude [101], due to a stronger response to summer temperatures at northern latitudes, suggesting that herbivory will likely increase at higher latitudes with climate warming. Host plant preferences can also change at warmer temperatures. Jing et al. [140] measured developmental parameters of three defoliators and their preferences for five host plants at temperatures from 16 to $31{ }^{\circ} \mathrm{C}$ and showed 
Table 4 Effects of climate change on forest insect communities

\begin{tabular}{|c|c|c|c|c|c|c|}
\hline Guild & Biome & Region & Species & Host & Approach & References \\
\hline \multirow[t]{7}{*}{ Defoliators } & \multirow[t]{4}{*}{ Boreal } & Finland & Moths & NA & Time series light trapping (also outbreak) & {$[135]$} \\
\hline & & Russia & Several taxa & NA & Time series & {$[136]$} \\
\hline & & Finland & Several taxa & Betula & Effect of temperature on communities & {$[137]$} \\
\hline & & Finland & Leaf miners & NA & Latitudinal gradient & {$[101]$} \\
\hline & \multirow[t]{3}{*}{ Temperate } & N. America & & Betula, Populus & $\mathrm{CO}_{2}, \mathrm{O}_{3} \mathrm{FACE}$ & [138] \\
\hline & & N. America & Chaitophorus populicola & Populus & FACE and insect mutualism & [139] \\
\hline & & Eastern China & Lepidoptera & Various & Species response to temperature & [140] \\
\hline \multirow{2}{*}{$\begin{array}{c}\text { Bark beetles and } \\
\text { wood borers }\end{array}$} & \multirow[t]{2}{*}{ Temperate } & Europe & Bark beetles & Picea & Effect of temperature on communities & {$[141]$} \\
\hline & & C. America & Bark beetles & Pinus & Effect of temperature on communities & {$[142]$} \\
\hline Other guilds & Temperate & S. Korea & Beetles & & Effect of temperature on communities & [143] \\
\hline
\end{tabular}

that with increase in temperature, development time was shorter, and survival rate and fitness increased. A shift in feeding preference for host plants also occurred, leading to increased herbivory on certain plants and a potential altering of forest communities.

Sensitivity of communities to climate warming can be studied using elevation gradients to monitor community responses to variation in temperature and precipitation. In a temperate forest on Changbai Mountain in China, ground beetle and geometrid moth assemblages shifted more strongly with altitude compared to changes in vegetation, suggesting that climate change will facilitate a shift in their distribution, and raising concerns about extinction of mountain-top communities that may be unable to move further uphill [145]. The effect of future atmospheres on forest insect communities have also been explored with $\mathrm{CO}_{2}$ enrichment studies [138]. The effects of $\mathrm{CO}_{2}$ and $\mathrm{O}_{3}$ on herbivore abundance and species richness did not significantly alter aspen arthropod community composition, but occasionally altered birch insect community composition, suggesting that spatiotemporal responses of insect communities are difficult to predict, because of their variability.

Changes due to climate warming may not necessarily result in serious, long-term deleterious effects on communities or ecosystems. Population dynamics of subarctic moth assemblages were observed over 32 years in Finnish Lapland where there were rapid increases in temperature and precipitation in the study site [135]. Even though populations increased over this period, per capita rates of change were negatively associated with climate change variables in time series models. It appears that negative effects of climate change on population growth can be buffered by other ecological factors [135, 139].

\section{Bark Beetles and Wood Borers}

In Europe, trapping bark beetles along an altitudinal gradient revealed that there was no effect of elevation on species richness. There was a positive relationship between the abundance of aggressive tree-killing beetles and temperature, while less aggressive species exhibited the opposite trend [141]. The authors suggest that with warming, spruce forests may face increasing damage from aggressive species, threatening growth and survival of Norway spruce at low elevations and southern latitudes. Similar patterns were observed in Mexico in nonaggressive, pine-infesting bark beetles along an altitudinal gradient [142]. Species richness and abundance were highest at the lowest elevation and there was a positive relationship between temperature and bark beetle abundance. At lower elevations, projected rise in temperature is predicted to cause higher damage by bark beetles on susceptible tree species.

Predators, competitors, and mutualists play an important role in the population dynamics of bark beetles. Predators such as woodpeckers, clerid beetles, and flies can cause high mortality on adult beetles and larvae [146]. The direct impacts of warming on predation rates and bark beetle performance are not known, and we need to consider phenological responses of natural enemies to changes in temperature regimes in future studies [15•]. Warm temperatures can directly and indirectly influence the composition of mutualistic fungi and determine beetle fitness. Simulations of temperature variability on persistence of fungi in mutualistic associations with $D$. ponderosae showed that thermal migration between warm and cool conditions would stabilize mutualisms in the longterm [147]. If climate change forces one of the main mutualists out of the association, beetle fitness and outbreak potential could decrease [147].

\section{Other Guilds}

Ecological factors and community interactions appear to moderate the responses that warming might elicit. In open-top warming experiments, populations of the aphid, Chaitophorus populicola, were higher when tended by mutualistic ants, regardless of temperature [139]. In their study, plant stress decreased with warming only when both ants and $C$. populicola aphids were associated in mutualistic 
interactions, suggesting that such interspecific interactions could buffer the effects of warming on herbivore communities. Temperature-based predictions of beetle abundance from several families in South Korea indicate that species can vary in their response to temperature [143]. Of the 18 species they analyzed, 6 were predicted to increase in abundance and 12 were predicted to decrease. They predicted that as the climate warms, more beetle species will decrease in abundance. There are very few studies on climate change and tropical insect communities. A unique study using a 137-month time series of 100 species of fruit-feeding butterflies in Uganda showed that temporal shifts in peaks of butterfly abundance were correlated with temporal shifts in peaks of vegetation greenness depending on temperature and precipitation, and that assemblages of ENSO warm phase years differed from other years [148]. Projected changes in climate can be used to predict patterns of species distribution and richness. Distribution models for 43 species of flightless Australian ground beetles suggest that with upward shifts in distribution, species currently confined to lower and drier mountain ranges will be more vulnerable to climate change impacts than those restricted to the highest and wettest mountains. Poor ecological conditions would make communities more susceptible to the negative consequences of climate change.

\section{Conclusions}

1. Information available on the relationships between climate change and forest insects has increased in the last few years. The effects of climate change are clear in some species, but cannot be generalized to all species, even within the same guild or biome. The direction of the effect of climate change can vary from positive to negative and it is often difficult to disentangle indirect and direct effects, as well as tri-trophic interactions. Predictions based on the link between climate change and insect disturbances are important, as insects are critical to forest succession [5, 149]. Modeling is a useful tool, although predictions can be misleading when input data are scarce or not appropriate. The mechanistic nature of process-based phenology models permit predictions of population dynamics in a changing climate [63•].

2. In both defoliators and bark and wood-boring insects, relationships between tree mortality and environmental factors provide strong evidence that changes in magnitude, frequency, and intensity of recent outbreaks are driven by direct or indirect effects of climate. Warm temperatures can decrease winter mortality and diapause requirements, thereby shortening generation time and increasing voltinism. Indirect positive effects on insects can occur through deleterious effects of warm temperatures and drought on defenses of host trees. Species-specific responses to temperature can result in variable impacts of climate change on outbreak behavior.

3. Several species of defoliators and bark beetles now have higher survival and reproductive rates at high elevations and more northern latitudes than in the past. Populations are therefore expanding into new ranges, affecting novel and evolutionarily naïve host species. Novel host species are not equipped with the same defense capacities as coevolved hosts and can suffer greater damage from herbivory. Whether or not forest ecosystems will be resilient to disturbance regimes they have not co-evolved with, requires long-term monitoring of forest regeneration and ecosystem impacts.

4. Climate change can disrupt trophic interactions depending on species-specific responses of individuals at each trophic level to increase in temperature. More studies are needed on the temperature dependence of functional responses of predator-prey systems to predict the outcomes of climate change scenarios. To this end, functional response settings added to greenhouse studies or field mesocosm experiments can be used to evaluate physiological and behavioral responses to increase in ambient temperature across trophic levels and assess the extent to which climate change will alter trophic interactions.

5. Mechanistic studies linking climate change variables to plant and insect performance are needed, especially when factors other than temperature are considered. Microcosm studies with $\mathrm{CO}_{2}$ or $\mathrm{O}_{3}$ enrichment treatments, or rainfall simulations with closed-top chambers can be used to measure plant and insect responses to modified conditions under climate change.

6. Historical datasets about herbivory in forests can be used to reconstruct damage dynamics in relation to climate change, provided the role of the main variables can be disentangled $[102,150]$. Climate change studies conducted so far concern mainly temperate and boreal forests. More research is needed on the impact of climate change on species and communities in subtropical and tropical forests.

Acknowledgements The authors thank Paolo Paolucci for drawing Fig. 1. Comments and suggestions from two anonymous reviewers helped improve the manuscript.

Funding The authors thank the University of Padova for a visiting scientist grant 2017, the Canadian Forest Service for research funds (O\&M) and the Natural Sciences and Engineering Research Council of Canada for a Discovery Grant to DSP.

\section{Compliance with Ethical Standards}

Conflict of Interest The authors have no conflicts of interests to declare.

Human and Animal Rights and Informed Consent This article contains no studies with human or animal subjects performed by the authors. 
Open Access This article is distributed under the terms of the Creative Commons Attribution 4.0 International License (http:// creativecommons.org/licenses/by/4.0/), which permits unrestricted use, distribution, and reproduction in any medium, provided you give appropriate credit to the original author(s) and the source, provide a link to the Creative Commons license, and indicate if changes were made.

\section{References}

Papers of particular interest, published recently, have been highlighted as:

- Of importance

•- Of major importance

1.• Field CB, Barros VR, Mach KJ, Mastrandrea MD, van Aalst M, Adger WN, Arent DJ, Barnett J, Betts R, Bilir TE, Birkmann J, Carmin J, Chadee DD, Challinor AJ, Chatterjee M, Cramer W, Davidson DJ, Estrada YO, Gattuso J-P, Hijioka Y, HoeghGuldberg O, Huang HQ, Insarov GE, Jones RN, Kovats RS, Romero-Lankao P, Larsen JN, Losada IJ, Marengo JA, McLean RF, Mearns LO, Mechler R, Morton JF, Niang I, Oki T, Olwoch JM, Opondo M, Poloczanska ES, Pörtner H-O, Redsteer MH, Reisinger A, Revi A, Schmidt DN, Shaw MR, Solecki W, Stone DA, Stone JMR, Strzepek KM, Suarez AG, Tschakert P, Valentini R, Vicuña S, Villamizar A, Vincent KE, Warren R, White LL, Wilbanks TJ, Wong PP, and Yohe GW. Technical summary. In: Field CB, Barros VR, Dokken DJ, Mach KJ, Mastrandrea MD, Bilir TE, Chatterjee M, Ebi KL, Estrada YO, Genova RC, Girma B, Kissel ES, Levy AN, MacCracken S, Mastrandrea PR, and White LL. Editors. Climate change 2014: Impacts, adaptation, and vulnerability. Part A: global and sectoral aspects. Contribution of working group II to the fifth assessment report of the intergovernmental panel on climate change. Cambridge University Press, Cambridge; pp. 35-94. Sets the scene for current and future climate change research.

2. Nicholls N. et al. Observed climate variability and change. In: Climate change 1995: the science of climate change. Intergovernmental Panel on Climate Change (IPCC). Cambridge Univ. Press, Cambridge; 1996. p. 133.

3. Christensen JH, Hewitson B, Busuioc A et al. Regional climate projections. In: Solomon S, Qin D, Manning M, Chen Z, Marquis M, Averyt KB, Tignor M, Miller HL. Editors. Climate change 2007: the physical science basis. Contribution of Working Group I to the Fourth Assessment Report of the Intergovernmental Panel on Climate Change. Cambridge University Press, Cambridge; 2007. pp. 847-940.

4. Price DT, Alfaro RI, Brown KJ, Flannigan MD, Fleming RA, Hogg EH, et al. Anticipating the consequences of climate change for Canada's boreal forest ecosystems. Environ Rev. 2013;21: 322-65.

5. Seidl R, Thom D, Kautz M, Martin-Benito D, Peltoniemi M, Vacchiano G, et al. Forest disturbances under climate change. Nat Clim Chang. 2017;76:395-402.

6. Kurz WA, Dymond CC, Stinson G, Rampley GJ, Neilson ET, Carroll AL, et al. Mountain pine beetle and forest carbon feedback to climate change. Nature. 2008;452:987-90. One of the largest ever documented impacts of an insect on forest and carbon cycle.

7. Anderegg WRL, Hicke JA, Fisher RA, Allen CD, Aukema J, Bentz B, et al. Tree mortality from drought, insects, and their interactions in a changing climate. New Phytol. 2015;208:674-83.
8. Millar CI, Stephenson NL. Temperate forest health in an era of emerging megadisturbance. Science. 2015;349:823-6.

9. Williams DW, Liebhold AM. Climate change and the outbreak ranges of two north American bark beetles. Agric For Entomol. 2002;4:87-99.

10. Raffa KF, Aukema BH, Barbara J, Bentz BJ, Carroll AL, Hicke JA JA, et al. Cross-scale drivers of natural disturbances prone to anthropogenic amplification: the dynamics of bark beetle eruptions. Bioscience. 2008;58:501-17.

11. Myers JH, Cory JS. Population cycles in forest Lepidoptera revisited. Annu Rev Ecol Evol Syst. 2013;44:565-92. A thorough review on major factors affecting Lepidoptera population cycles.

12. Allstadt AJ, Haynes KJ, Liebhold AM, Johnson DM. Long-term shifts in the cyclicity of outbreaks of a forest-defoliating insect. Oecologia. 2013;172:141-51.

13. Cooper LA, Ballantyne AP, Holden ZA, Landguth EL. Disturbance impacts on land surface temperature and gross primary productivity in the western United States. J Geophys Res Biogeosci. 2017;122:930-46.

14. Williams CA, Gu H, MacLean R, Masek JG, Collatz GJ. Disturbance and the carbon balance of US forests: a quantitative review of impacts from harvests, fires, insects, and droughts. Glob Planet Chang. 2016;143:66-80.

15. Raffa KF, Aukema BH, Bentz BJ, Carroll AL, Hicke, J.A., Kolb, T.E. Responses of tree-killing bark beetles to a changing climate. In: Bjorkman C, Niemela P. Climate change and insect pests. 2015. CAB international; pp. 173-201. An overview of relationships between climate change and bark beetle outbreaks.

16. Bentz BJ, Regniere J, Fettig CJ, Hansen EM, Hayes JL, Hicke JA, et al. Climate change and bark beetles of the western United States and Canada: direct and indirect effects. Bioscience. 2010;60:60213.

17. Candau J-N, Fleming R. Forecasting the response of spruce budworm defoliation to climate change in Ontario. Can J For Res. 2011;41:1948-60.

18. Pureswaran DS, De Grandpré LD, Paré D, Taylor A, Barrette M, Morin H, et al. Climate-induced changes in host tree-insect phenology may drive ecological state-shift in boreal forests. Ecology. 2015;96:1480-91.

19. Johnson DM, Bjørnstad ON, Liebhold AM. Landscape geometry and travelling waves in the larch budmoth. Ecol Lett. 2004;7:96774.

20. Weed AS, Ayres MP, Hicke JA. Consequences of climate change for biotic disturbances in north American forests. Ecol Monogr. 2013;83:441-70.

21. Bebber DP. Range expanding pests and pathogens in a warming world. Annu Rev Phytopathol. 2015;53:335-56.

22. Robinet C, Rousselet J, Roques A. Potential spread of the pine processionary moth in France: preliminary results from a simulation model and future challenges. Ann For Sci. 2014;71:149-60.

23. Battisti A, Stastny M, Buffo E, Larsson S. A rapid altitudinal range expansion in the pine processionary moth produced by the 2003 climatic anomaly. Glob Chang Biol. 2006;12:662-71.

24. Su T, Adams JM, Wappler T, Huang Y-J, Jacques FMB, Liu Y-S, et al. Resilience of plant-insect interactions in an oak lineage through quaternary climate change. Paleobiol. 2015;41:174-86.

25. Jepsen JU, Biuw M, Ims RA, Kapari L, Schott T, Vindstad OPL, et al. Ecosystem impacts of a range expanding forest defoliator at the forest-tundra ecotone. Ecosystems. 2013;16:561-75. Demonstrates the cascading effects of climate-induced outbreak of forest defoliators on northern ecosystem dynamics.

26. Haynes KJ, Allstadt AJ, Klimetzek D. Forest defoliator outbreaks under climate change: effects on the frequency and severity of outbreaks of five pine insect pests. Glob Chang Biol. 2014;20: 2004-18. 
27. Klapwijk MJ, Csóka G, Hirka A, Björkman C. Forest insects and climate change: long-term trends in herbivore damage. Ecol Evol. 2013;3:4183-96.

28. Boulanger Y, Arseneault D, Morin H, Jardon Y, Bertrand P, Dagneau C. Dendrochronological reconstruction of spruce budworm (Choristoneura fumiferana) outbreaks in southern Quebec for the last 400 years. Can J For Res. 2012;42:1264-76.

29. Clark JS, Iverson L, Woodall CW, Allen CD, Bell DM, Bragg DC, et al. The impacts of increasing drought on forest dynamics, structure, and biodiversity in the United States. Glob Chang Biol. 2016;22:2329-52.

30. Huey RB, Berrigan D, Gilchr GW, Herron JC. Testing the adaptive significance of acclimation: a strong inference approach. Amer Zool. 1999;39:323-36.

31. Leppanen C, Simberloff D. Implications of early production in an invasive forest pest. Agr For Entomol. 2017;19:217-24.

32. Kolb TE, Fettig CJ, Ayres MP, Bentz BJ, Hicke JA, Mathiasen R, Stewart JE, Weed AS. Observed and anticipated impacts of drought on forest insects and diseases in the United States For Ecol Manag 2016;380:321-334

33. Roitberg BD, Mangel M. Cold snaps and heat waves on arthropods. Ecol Entomol. 2016;41:653-9.

34. Furlong MJ, Zalucki MP. Climate change and biological control: the consequences of increasing temperatures on host-parasitoid interactions. Curr Opin Insect Sci. 2017;20:39-44.

35. Myers JH, Sarfraz RM. Impacts of insect herbivores on plant populations. Annu Rev Entomol. 2017;62:207-30.

36. Chung H, Muraoka H, Nakamura M, Han S, Muller O, Son Y. Experimental warming studies on tree species and forest ecosystems: a literature review. J Plant Res. 2013;126:447-60.

37. Schwartzberg EG, Jamieson MA, Raffa KF, Reich PB, Montgomery RA, Lindroth RL. Simulated climate warming alters phenological synchrony between an outbreak insect herbivore and host trees. Oecologia. 2014;175:1041-9.

38. Jamieson MA, Schwartzberg EG, Raffa KF, Reich PB, Lindroth RL. Experimental climate warming alters aspen and birch phytochemistry and performance traits for an outbreak insect herbivore. Glob Chang Biol. 2015;21:2698-710.

39. Uelmen JA Jr, Lindroth RL, Tobin PC, Reich PB, Schwartzberg EG, Raffa KF. Effects of winter temperatures, spring degree-day accumulation, and insect population source on phenological synchrony between forest tent caterpillar and host trees. For Ecol Manag. 2016;362:241-50.

40. Fordham DA. Mesocosms reveal ecological surprises from climate change. PLoS Biol. 2015;13:e1002323.

41. Battisti A, Larsson S. Climate change and insect pest distribution range. In: Bjorkman $\mathrm{C}$ and Niemela P. Editors. Climate change and insect pests. $C A B$ international; 2015. p. 1-15. Provides conceptual framework for the study of range expansion of insects in relation to climate change.

42. Robinet C, Baier P, Pennerstorfer J, Schopf A, Roques A. Modelling the effects of climate change on the potential feeding activity of Thaumetopoea pityocampa (Den. \& Schiff.) (Lep., Notodontidae) in France. Glob Ecol Biogeog. 2007;16:460-71.

43. Blackburn TM, Pyšek P, Bacher S, Carlton JT, Duncan RP, et al. (2011) A proposed unified framework for biological invasions. TREE. 2011; 26:333-339.

44. Régnière J, St-Amant R, Duval P. Predicting insect distributions under climate change from physiological responses: spruce budworm as an example. Biol Invas. 2012;14:1571-86.

45. Gray DR. Quantifying the sources of epistemic uncertainty in model predictions of insect disturbances in an uncertain climate. Ann For Sci. 2017;74:48.

46. Jepsen JU, Hagen SB, Ims RA, Yoccoz NG. Climate change and outbreaks of the geometrids Operophtera brumata and Epirrita autumnata in subarctic birch forest: evidence of a recent outbreak range expansion. J Anim Ecol. 2008;77:257-64.

47. Ammunét T, Kaukoranta T, Saikkonen K, Repo T, Klemola T. Invading and resident defoliators in a changing climate: cold tolerance and predictions concerning extreme winter cold as a rangelimiting factor. Ecol Entomol. 2012;37:212-20.

48. Thompson LM, Faske TM, Banahene N, Grim D, Agosta SJ, Parry D, Tobin PC, Johnson DM, Grayson KL. Variation in growth and developmental responses to supraoptimal temperatures near latitudinal range limits of gypsy moth Lymantria dispar (L.), an expanding invasive species. Physiol Entomol. 2017; https://doi.org/10.1111/phen.

49. Battisti A, Stastny M, Netherer S, Robinet C, Schopf A, Roques A, et al. Expansion of geographic range in pine processionary moth caused by increasing winter temperatures. Ecol Appl. 2005;15:2084-96.

50. Robinet C, Imbert CE, Rousselet J, Sauvard D, Garcia J, Goussard $\mathrm{F}$, et al. Human-mediated long-distance jumps of the pine processionary moth in Europe. Biol Invas. 2012;14:1557.

51. Esper J, Büntgen U, Frank DC, Nievergelt D, Liebhold A. 1200 years of regular outbreaks in alpine insects. Proc Royal Soc Biol Sci. 2007;274:671-9.

52. Johnson DM, Büntgen U, Frank DC, Kausrud K, Haynes KJ, Liebhold AM, et al. Climatic warming disrupts recurrent alpine insect outbreaks. Proc Natl Acad Sci U S A. 2010;107:20576-81.

53. Muirhead JR, Leung B, Van Overdijk C, Kelly DW, Nandakumar $\mathrm{K}$, Marchant KR, et al. Modelling local and long-distance dispersal of invasive emerald ash borer, Agrilus planipennis (Coleoptera) in North America. Diver Distrib. 2006;12:71-9.

54. Ungerer MJ, Ayres MP, Lombardero MJ. Climate and the northern distribution limits of Dendroctonus frontalis Zimmermann (Coleoptera: Scolytidae). J Biogeogr. 1999;26:1133-45.

55. Trân JK, Ylioja T, Billings RF, Régnière J, Ayres MP. Impact of minimum winter temperatures on the population dynamics of Dendroctonus frontalis. Ecol Appl. 2007;17:882-99.

56. De la Giroday HMC, Carroll AL, Aukema BH. Breach of the northern Rocky Mountain geoclimatic barrier: initiation of range expansion by the mountain pine beetle. J Biogeogr. 2012;39: 1112-23.

57. Sidder AM, Kumar S, Laituri M, Sibold JS. Using spatiotemporal correlative niche models for evaluating the effects of climate change on mountain pine beetle. Ecosphere. 2016;7:e01396.

58. Adams AS, Aylward FO, Adams SM, Erbilgin N, Aukema BH, Currie CR, et al. Mountain pine beetles colonizing historical and naïve host trees are associated with a bacterial community highly enriched in genes contributing to terpene metabolism. Appl Environ Microbiol. 2013;79:3468-75.

59. Raffa KF, Powell EN, Townsend PA. Temperature-driven range expansion of an irruptive insect heightened by weakly coevolved plant defenses. Proc Natl Acad Sci USA. 2013;110:2193-8. Describes the interactions of the mountain pine beetle with a novel host plant.

60. Janes JK, Li Y, Keeling CI, Yuen MMS, Boone CK, Cooke JEK, et al. How the mountain pine beetle (Dendroctonus ponderosae) breached the Canadian rocky mountains. Mol Biol Evol. 2014;31: 1803-15.

61. Bentz B, Vandygriff J, Jensen C, Coleman T, Maloney P, Smith S, et al. Mountain pine beetle voltinism and life history characteristics across latitudinal and elevational gradients in the western United States. For Sci. 2014;60:434-49.

62. Bentz BJ, Duncan JP, Powell JA. Elevational shifts in thermal suitability for mountain pine beetle population growth in a changing climate. Forestry. 2016;89:271-83.

63. Bentz BJ, Jönsson AM. Modeling bark beetle responses to climate change. In: Vega FE, Hofstetter RW, editors. Bark beetles. San Diego: Academic press; 2015. p. 533-53. Reviews the modeling 
approach to the bark beetle dynamics under a climate change scenario.

64. Smith SE, Mendoza MG, Zúñiga G, Halbrook K, Hayes JL, Byrne DN. Predicting the distribution of a novel bark beetle and its pine hosts under future climate conditions. Agr For Entomol. 2013;15: 212-26.

65. Barredo JI, Strona G, de Rigo D, Caudullo G, Stancanelli G, SanMiguel-Ayanz J. Assessing the potential distribution of insect pests: case studies on large pine weevil (Hylobius abietis L) and horse-chestnut leaf miner (Cameraria ohridella) under present and future climate conditions in European forests. EPPO Bulletin. 2015;45:273-81.

66. Walker P, Leather SR, Crawley MJ. Differential rates of invasion in three related alien oak gall wasps (Cynipidae: hymenoptera). Diver Distrib. 2002;8:335-49.

67. EFSA and Panel on Plant Health. Risk assessment of the oriental chestnut gall wasp, Dryocosmus kuriphilus for the EU territory on request from the European Commission. EFSA J. 2010;8:1-114.

68. Paradis A, Elkinton J, Hayhoe K, Buonaccorsi J. Role of winter temperature and climate change on the survival and future range expansion of the hemlock woolly adelgid (Adelges tsugae) in eastern North America. Mitig Adapt Strat Glob Change. 2008;13: 541-54.

69. Fitzpatrick MC, Preisser EL, Porter A, Elkinton J, Ellison AM. Modeling range dynamics in heterogeneous landscapes: invasion of the hemlock woolly adelgid in eastern North America. Ecol Appl. 2012;22:472-86.

70. Boulanger Y, Gray DR, Cooke BJ, De Grandpré L. Modelspecification uncertainty in future forest pest outbreaks. Glob Chang Biol. 2016;22:1595-607.

71. Cooke BJ, Carroll AL. Predicting the risk of mountain pine beetle spread to eastern pine forests: considering uncertainty in uncertain times. For Ecol Manag. 2017;396:11-25.

72. Buffo E, Battisti A, Stastny M, Larsson S. Temperature as a predictor of survival of the pine processionary moth in the Italian alps. Agric For Entomol. 2007;9:65-72.

73. Hof AR, Svahlin A. The potential effect of climate change on the geographical distribution of insect pest species in the Swedish boreal forest. Scand J For Res. 2016;31:29-39.

74. Björklund N, Lindelöw Å, Schroeder LM. Erroneous conclusions about current geographical distribution and future expansion of forest insects in northern Sweden: comments on Hof and Svahlin (2015). Scand J for Res. 2016;31:126-7.

75. Hof AR, Svahlin A. Not erroneous but cautious conclusions about the potential effect of climate change on the geographical distribution of insect pest species in the Swedish boreal forest. Response to Björklund et al. (2015). Scand J For Res. 2016;31: $128-9$.

76. Lantschner MV, Villacide JM, Garnas JR, Croft P, Carnegie AJ, Liebhold AM, et al. Temperature explains variable spread rates of the invasive woodwasp, Sirex noctilio, in the southern hemisphere. Biol Invas. 2014;16:329-39.

77. Tobin PC, Turcotte RM, Blackburn LM, Juracko JA, Simpson BT. The big chill: quantifying the effect of the 2014 north American cold wave on hemlock woolly adelgid populations in the central Appalachian Mountains. Popul Ecol 2017; https://doi.org/10. 1007/s10144-017-0589-y.

78. Roques A, Auger-Rozenberg M-A, Blackburn TM, Garnas J, Pyšek P, Rabitsch W, et al. Temporal and interspecific variation in rates of spread for insect species invading Europe during the last 200 years. Biol Invas. 2016;18:907-20.

79. Fierravanti A, Cocozza C, Palombo C, Rossi S, Deslauriers A, Tognetti R. Environmental-mediated relationships between tree growth of black spruce and abundance of spruce budworm along a latitudinal transect in Quebec. Canada Agr For Meteorol. 2015;213:53-63.
80. Robson JRM, Conciatori F, Tardif JC, Knowles K. Tree-ring response of jack pine and scots pine to budworm defoliation in Central Canada. For Ecol Manag. 2015;347:83-95.

81. Zvereva EL, Hunter MD, Zverev V, Kozlov MV. Factors affecting population dynamics of leaf beetles in a subarctic region: the interplay between climate warming and pollution decline. Sci Tot Environ. 2016;566-567:1277-88.

82. Pepi AA, Vinstad OPL, Ek M, Jepsen JU. Elevationally biased avian predation as a contributor to the spatial distribution of geometrid moth outbreaks in sub-arctic mountain birch forest. Ecol Entomol. 2017. https://doi.org/10.1111/een.12400.

83. Visser ME, Holleman LJM. Warmer springs disrupt the synchrony of oak and winter moth phenology. Proc Royal Soc Lond B - Biol Sci. 2001;268:289-94.

84. Kivimäenpää M, Ghimire RP, Sutinen S, Häikiö E, Kasurinen A, Holopainen T, et al. Increases in volatile organic compound emissions of scots pine in response to elevated ozone and warming are modified by herbivory and soil nitrogen availability. Eur J For Res. 2016;135:343-60.

85. Voolma K, Hiiesaar K, Williams IH, Ploomi A, Jõgar K. Cold hardiness in the pre-imaginal stages of the great web-spinning pine-sawfly Acantholyda posticalis. Agr For Entomol. 2016;18: 432-6.

86. Flower A, Gavin DG, Heyerdahl EK, Parsons RA, Cohn GM. Western spruce budworm outbreaks did not increase fire risk over the last three centuries: a dendrochronological analysis of interdisturbance synergism. PLoS One 2014; 9.

87. Backhaus S, Wiehl D, Beierkuhnlein C, Jentsch A, Wellstein C. Warming and drought do not influence the palatability of Quercus pubescens Willd. leaves of four European provenances. Arthropod-Plant Interact. 2014:8:329-37.

88. Foster JR, Townsend PA, Mladenoff DJ. Mapping asynchrony between gypsy moth egg-hatch and forest leaf-out: putting the phenological window hypothesis in a spatial context. For Ecol Manag. 2013;287:67-76.

89. Youngsteadt E, Dale AG, Terando AJ, Dunn RR, Frank SD. Do cities simulate climate change? A comparison of herbivore response to urban and global warming. Glob Chang Biol. 2015;21: 97-105.

90. Kollberg I, Bylund H, Schmidt A, Gershenzon J, Björkman C. Multiple effects of temperature, photoperiod and food quality on the performance of a pine sawfly. Ecol Entomol. 2013;38:201-8.

91. Roques A. Processionary moths and climate change: an update. 2015; Springer-Quae, Dordrecht. An overview of the processionary moths and their relationships with climate change.

92. Tamburini G, Marini L, Hellrigl K, Salvadori C, Battisti A. Effects of climate and density-dependent factors on population dynamics of the pine processionary moth in the southern alps. Climat Chang. 2013;121:701-12.

93. Saulnier M, Roques A, Guibal F, Rozenberg P, Saracco G, Corona $\mathrm{C}$, et al. Spatiotemporal heterogeneity of larch budmoth outbreaks in the French Alps over the last 500 years. Can J For Res. 2017;47: 667-80.

94. Agosta SJ, Hulshof CM, Staats EG. Organismal responses to habitat change: herbivore performance, climate and leaf traits in regenerating tropical dry forests. J Anim Ecol. 2017;86:590-604.

95. DeSantis RD, Moser WK, Gormanson DD, Bartlett MG, Vermunt B. Effects of climate on emerald ash borer mortality and the potential for ash survival in North America. Agr For Meteorol. 2013;178-179:120-8.

96. Rosenberger DW, Venette RC, Maddox MP, Aukema BH. Colonization behaviors of mountain pine beetle on novel hosts: implications for range expansion into Northeastern North America. PLoS ONE. 2017; https://doi.org/10.1371/journal. pone. 0176269 . Uses manipulative experiments to test 
susceptibility of naïve host species to a range-expanding, treekilling pest.

97. Berec L, Doležal P, Hais M. Population dynamics of Ips typographus in the Bohemian Forest (Czech Republic): validation of the phenology model PHENIPS and impacts of climate change. For Ecol Manag. 2013;292:1-9.

98. David G, Giffard B, Piou D, Roques A, Jactel H. Potential effects of climate warming on the survivorship of adult Monochamus galloprovincialis. Agr For Entomol. 2017;19:192-9.

99. Baier P, Pennerstorfer J, Schopf A. PHENIPS - a comprehensive phenology model of Ips typographus (L.) (Col., Scolytinae) as a tool for hazard rating of bark beetle infestation. For Ecol Manag. 2007;249:171-86.

100. Inward DJG, Wainhouse D, Peace A. The effect of temperature on the development and life cycle regulation of the pine weevil, Hylobius abietis and the potential impacts of climate change. Agr For Entomol. 2012;14:348-57.

101. Kozlov MV, van Nieukerken EJ, Zverev V, Zvereva EL. Abundance and diversity of birch-feeding leaf miners along latitudinal gradients in northern Europe. Ecography. 2013;36:113849.

102. Kozlov MV, Zverev V, Zvereva EL. Combined effects of environmental disturbance and climate warming on insect herbivory in mountain birch in subarctic forests: results of 26-year monitoring. Sci Tot Environ. 2017;601-602:802-11.

103. Banfield-Zanin JA, Leather SR. Season and drought stress mediate growth and weight of the green spruce aphid on Sitka spruce. Agr For Entomol. 2015;17:48-56.

104. Gherlenda AN, Esveld JL, Hall AAG, Duursma RA, Riegler M. Boom and bust: rapid feedback responses between insect outbreak dynamics and canopy leaf area impacted by rainfall and $\mathrm{CO}_{2}$. Glob Chang Biol. 2016;22:3632-41.

105. Gherlenda AN, Moore BD, Haigh AM, Johnson SN, Riegler $\mathrm{M}$. Insect herbivory in a mature eucalyptus woodland canopy depends on leaf phenology but not $\mathrm{CO}_{2}$ enrichment. BMC Ecol. 2016;16:47.

106. Stireman JOIII, Dyer LA, Janzen DH, Singer MS, Lill JT, Marquis RJ, et al. Climatic unpredictability and parasitism of caterpillars: implications of global warming. Proc Natl Acad Sci. 2005;102: 17384-7.

107. Berggren $\AA$, Björkman C, Bylund H, Ayres MP. The distribution and abundance of animal populations in a climate of uncertainty. Oikos. 2009;118:1121-6.

108. van Asch M, Visser ME. Phenology of forest caterpillars and their host trees: the importance of synchrony. Annu Rev Entomol. 2007;52:37-55

109. Dixon AFG. Climate change and phenological asynchrony. Ecol Entomol. 2003;28:380-1.

110. Logan JA, Powell JA. Ghost forests, global warming, and the mountain pine beetle (Coleoptera: Scolytidae). Am Entomol. 2001;47:160-73.

111. Sambaraju KR, Carroll AL, Zhu J, Stahl K, Moore RD, Aukema BH. Climate change could alter the distribution of mountain pine beetle outbreaks in western Canada. Ecography. 2012;35:211-23.

112. Schebeck M, Hansen M, Schopf A, Gregory J, Ragland C, Bentz BJ. Diapause and overwintering of two spruce bark beetle species. Phys Entomol. 2017;42:200-10.

113. Marini L, Ayres MP, Battisti A, Faccoli M. Climate affects severity and altitudinal distribution of outbreaks in an eruptive bark beetle. Climat Chang. 2012;115:327-41.

114. Wainhouse D, Inward DJG, Morgan G. Modelling geographical variation in voltinism of Hylobius abietis under climate change and implications for management. Agr For Entomol. 2014;16: $136-46$.
115. Turgeon JJ, Roques A, de Groot P. Insect fauna of coniferous seed cones: diversity, host plant interactions, and management. Annu Rev Entomol. 1994;39:179-212.

116. Sachet J-M, Poncet B, Roques A, Després L. Adaptive radiation through phenological shift: the importance of the temporal niche in species diversification. Ecol Entomol. 2009;34:81-9.

117. Poncet BN, Garat P, Manel S, Roques A, Despres L. The effect of climate on masting in the European larch and on its specific seed predators. Oecologia. 2009;159:527-37.

118. Jameson RG, Trant AJ, Hermanutz L. Insects can limit seed productivity at the treeline. Can J For Res. 2015;45:286 296.

119. Zhang X, Lei Y, Ma Z, Kneeshaw D, Peng C. Insect-induced tree mortality of boreal forests in eastern Canada under a changing climate. Ecol Evol. 2014;4:2384-94.

120. James PMA, Robert L-E, Wotton BM, Martell DL, Fleming RA. Lagged cumulative spruce budworm defoliation affects the risk of fire ignition in Ontario. Canada Ecol Appl. 2017;27:532-44.

121. Huttunen L, Saravesi K, Markkola A, Niemelä P. Do elevations in temperature, $\mathrm{CO}_{2}$, and nutrient availability modify belowground carbon gain and root morphology in artificially defoliated silver birch seedlings? Ecol Evol. 2013;3:2783-94.

122. Huttunen L, Ayres MP, Niemelä P, Heiska S, Tegelberg R, Rousi $\mathrm{M}$, et al. Interactive effects of defoliation and climate change on compensatory growth of silver birch seedlings. Silva Fennica. 2013;47:1-14.

123. Karlsen SR, Jepsen JU, Odland A, Ims RA, Elvebakk A. Outbreaks by canopy-feeding geometrid moth cause statedependent shifts in understorey plant communities. Oecologia. 2013;173:859-70.

124. Kharuk VI, Demidko DA, Fedotova EV, Dvinskaya ML, Budnik UA. Spatial and temporal dynamics of Siberian silk moth largescale outbreak in dark-needle coniferous tree stands in Altai. Contemp Prob Ecol. 2016;9:711-20.

125. de Groot M, Kogoj M. Temperature, leaf cover density and solar radiation influence the abundance of an oligophagous insect herbivore at the southern edge of its range. J Insect Conserv. 2015;19: 891-9.

126. Worrall JJ, Rehfeldt GE, Hamann A, Hogg EH, Marchetti SB, Michaelian M, et al. Recent declines of Populus tremuloides in North America linked to climate. For Ecol Manag. 2013;299:35-51.

127. Renwick KM, Rocca ME, Stohlgren TJ. Biotic disturbance facilitates range shift at the trailing but not the leading edge of lodgepole pine's altitudinal distribution. J Veget Sci. 2016;27: $780-8$.

128. Meigs GW, Zald HSJ, Campbell JL, Keeton WS, Kennedy RE. Do insect outbreaks reduce the severity of subsequent forest fires? Environ Res Lett. 2016; https://doi.org/10.1088/1748-9326/11/4/ 045008.

129. Mietkiewicz N, Kulakowski D. Relative importance of climate and mountain pine beetle outbreaks on the occurrence of large wildfires in the western USA. Ecol Appl. 2016;26:2523-35.

130. Arora VK, Peng Y, Kurz WA, Fyfe JC, Hawkins B, Werner AT. Potential near-future carbon uptake overcomes losses from a large insect outbreak in British Columbia. Canada Geophys Res Lett. 2016;43:2590-8

131. Landry J-S, Parrott L, Price D, Ramankutty N, Damon MH. Modelling long-term impacts of mountain pine beetle outbreaks on merchantable biomass, ecosystem carbon, albedo, and radiative forcing. Biogeosciences. 2016;13:5277-95.

132. Battisti A. Insects in forest ecosystems. In: Peh KS-H, Corlett RT, Bergeron Y, editors. Routledge handbook of forest ecology. Routledge: Oxon; 2015. p. 215-25.

133. Kurz WA, Apps MJ. A 70-year retrospective analysis of carbon fluxes in the Canadian forest sector. Ecol Appl. 2008;9:526-47. 
134. Logan JA, Macfarlane WW, Willcox L. Whitebark pine vulnerability to climate-driven mountain pine beetle disturbance in the greater Yellowstone ecosystem. Ecol Appl. 2010;20:895-902.

135. Hunter MD, Kozlov MV, Itämies J, Pulliainen E, Bäck J, Kyrö E$\mathrm{M}$, et al. Current temporal trends in moth abundance are counter to predicted effects of climate change in an assemblage of subarctic forest moths. Glob Chang Biol. 2014;20:1723-37.

136. Ovaskainen O, Skorokhodova S, Yakovleva M, Sukhov A, Kutenkov A, Kutenkova N, et al. Community-level phenological response to climate change. Proc Natl Acad Sci U S A. 2013;110: 13434-9.

137. Heimonen K, Valtonen A, Kontunen-Soppela S, Keski-Saari S, Rousi M, Oksanen E, et al. Susceptibility of silver birch (Betula pendula) to herbivorous insects is associated with the size and phenology of birch - implications for climate warming. Scand J For Res. 2017;32:95-104.

138. Hillstrom ML, Couture JJ, Lindroth RL. Elevated carbon dioxide and ozone have weak, idiosyncratic effects on herbivorous forest insect abundance, species richness, and community composition. Insect Conserv Diver. 2014;7:553-62.

139. Marquis M, Del Toro I, Pelini SL. Insect mutualisms buffer warming effects on multiple trophic levels. Ecology. 2014;95:9-13.

140. Jing J, Xia L, Li K. Development of defoliating insects and their preferences for host plants under varying temperatures in a subtropical evergreen forest in eastern China. Front Earth Sci. 2017;11:321-31.

141. Chinellato F, Faccoli M, Marini L, Battisti A. Distribution of Norway spruce bark and wood-boring beetles along alpine elevational gradients. Agr For Entomol. 2014;16:111-8.

142. Rubin-Aguirre A, Saenz-Romero C, Lindig-Cisneros R, del -RioMora AA, Tena-Morelos CA, Campos-Bolaños R, et al. Bark beetle pests in an altitudinal gradient of a Mexican managed forest. For Ecol Manag. 2015;343:73-9.

143. Kwon T-S, Lee CM, Kim S-S. Prediction of abundance of beetles according to climate warming in South Korea. J Asia-Pac Biodivers. 2015;8:7-30.

144. Péré C, Jactel H, Kenis M. Response of insect parasitism to elevation depends on host and parasitoid life-history strategies. Biol Lett. 2013;9:20130028.

145. Zou Y, Sang W, Axmacher JC. Resilience of insect assemblages to climate change in mature temperate mountain forests of NE China. J Insect Conserv. 2015;19:1163-72.

146. Turchin P, Taylor AD, Reeve JD. Dynamical role of predators in population cycles of a forest insect: an experimental test. Science. 1999;285:1068-71.

147. Addison AL, Powell JA, Six DL, Moore M, Bentz BJ. The role of temperature variability in stabilizing the mountain pine beetlefungus mutualism. J Theor Biol. 2013;335:40-50.

148. Valtonen A, Molleman F, Chapman CA, Carey JR, Ayres MP, Roininen H. Tropical phenology: bi-annual rhythms and interannual variation in an Afrotropical butterfly assemblage. Ecosphere. 2013;4:1-28.

149. Thom D, Rammer W, Dirnböck T, Müller J, Kobler J, Katzensteiner K, et al. The impacts of climate change and disturbance on spatio-temporal trajectories of biodiversity in a temperate forest landscape. J Appl Ecol. 2017;54:28-38.

150. Tudoran M-M, Marquer L, Jönsson AM. Historical experience (1850-1950 and 1961-2014) of insect species responsible for forest damage in Sweden: influence of climate and land management changes. For Ecol Manag. 2016;381:347-59. 